\title{
The Contribution of Land Banks in Indonesia To Create A Conducive Investment Climate to Accelerate Infrastructure Development
}

\author{
Andi Tenri Abeng \\ \{abengandi22@gmail.com\} \\ Doctor of Law, Universitas Jayabaya, Jakarta, Indonesia
}

\begin{abstract}
The realization of construction always requires land, and that makes land a commodity that makes prices rise while in construction for public use, whereas most often land acquisition is slow or even delayed. One solution to get land for construction is to apply land banks, especially public land that functions as land collectors, and land management media in exploiting and using land to be more productive by acquiring or buying land before it is needed so that the price is cheap. Land supply in the realization of construction always has problems that cause physical development in all areas of traffic jams or even delays due to inappropriate regulation and economic and political changes, from a democratic economy to an economy of neoliberal capitalism. That makes commodity land that triggers land liberalism. Land prices rise due to land speculators. One way to overcome the complexity of the problem of land supply for construction is to implement a land bank that has the function of land collectors, as a land protector to conserve supply and to exploit the land as a planned spatial plan that has been approved
\end{abstract}

Keywords: Land Bank, National Land Construction, Land Regulation

\section{Introduction}

The structure is one of the main pre-requisites for achieving sustainable economic growth (Eisenmenger, et., al. 2020; Wibowo, 2016; State Speech of the President of the Republic of Indonesia, 2006). The availability of adequate infrastructure causes the cost of production, transportation, communication, and logistics will be cheaper, the number of production increases, operating profits increase, so that it can increase people's income (Lélé, 1991; Munasinghe, 1999). The availability of infrastructure also accelerates equitable development to encourage new investment (Febrianto, 2020; Amir, et al. 2020; Cantarero, 2020; Brown, et al. 2020). Based on World Economic Forum (2014), Indonesia's competitiveness (Global Competitiveness Index-GCl) is ranked 34th in the world. Meanwhile, the Quality of Indonesia's infrastructure is ranked 56th out of 144 countries in the world. This infrastructure limitation is identified as the fourth obstacle to doing business in Indonesia after the inflation factor.

Therefore, it is fundamental for Indonesia to quickly in the development of adequate and sustainable infrastructure. In the current administration, nine priority agendas have been established called NAWA CITA (Rohman, \& Wahono, 2020; Gunawan, Permatasari, \& Tilt, 2020). The main focus one government's priority agenda is the construction of infrastructure in the form of construction of 2,650 Km of new roads and 1,000 Km of toll roads, 15 new airports, 24 new ports and crossing ports, construction of 3,258 km of railway lines, 49 new reservoirs and 33 hydropower plants, construction of an oil refinery, and also a power plant of 35,000 MW. 
In the process of implementing the infrastructure development program, land availability is still a major problem. One of the main obstacles in implementing the 35,000 MW power plant project island acquisition and acquisition. The same thing also happened in Riau, where land acquisition for the construction of the railroad track takes a long time and quite a large expenditure.

Law Number 2 of 2012 concerning Land Procurement for Development in the Public Interest and Presidential Regulation Number 71 of 2012 concerning the Provision of Land Procurement for Development in the Public Interest has not yet succeeded in being a solution to the problem of land acquisition and provision. Limbong (2015) argues that one of the concepts that should be considered in dealing with the complexity of the problem of land available for development in the public interest is the presence of a land bank. Limbong (2015) explained that substantially land banks carry out government land reserves to be used for the public interest as has been applied in several developed countries such as the Netherlands, Switzerland, Sweden, and the United States.

In addition to land requirements for infrastructure development, Indonesia is currently faced with the rapid development of property managed by the private sector. This has led to soaring land prices driven by high public demand for housing needs. In this case, the government must immediately take the role to conduct compliance and control of the property so that it is not too excessive which results in the investors taking advantage of these conditions. This is in line with the million -house construction program launched by the government. For this reason, it is necessary to develop a pattern of property management, especially land with a One Map Policy and the operation of the Land Bank as the main supporting instrument.

\section{The Real Estate Bank (Land Bank)}

The concept of the Land Bank has been introduced in the West since the 1700s which was later adopted by many countries including Asian countries. There are several notions about the Land Bank. According to Sumardjono (2005), the Land Bank is any government activity to provide land for future use. In this explanation, it is stated that the land bank mechanism is intended for the provision of land for public needs and public welfare so that government intervention is needed.

Conceptually, there are two forms of land banks, namely general land banking with the main mission of providing land for social needs on a large scale and not pursuing profits and maintaining land price stability. Second is special land banking tasked with providing land on a small scale for commercial purposes.

In terms of its function, a land bank has several functions (Harry, et al, 2020; Syed Mustorpha \& Tuan Besar, 2020): (1) land keeper, as a land collector, namely inventory and development of a land database, administration and provision of land information systems; (2) land warranty, as a security for the land, namely ensuring the supply of land for development, ensuring the value of land and the fair market efficiency of the land, and securing optimal land use; (3) land purchaser, as the controller of land, namely land ownership, land price determination related to the perception of the similarity in the value of land and building tax; (4) land valuer, as a land appraiser that is conducting land valuation that is objective in creating a value system in determining the value of land that applies to various purposes; (5) land distributor, as a land distributor, namely ensuring a fair and fair distribution of land based on the unity of land values, securing land planning, supply, and distribution; (6) land management, as a land manager that is conducting land management which is part and overall asset management, conducting analysis, establishing strategies, and managing implementation related to land. 


\section{Types of Land Bank}

In this connection, the organizer of the land bank should be in the form of a public legal entity. The constitutional court provides an interpretation of the state's controlling rights over the earth, water, space, and natural resources contained therein by the State, namely: not in the sense the State must-have, but the State only formulates policies (regulations), makes arrangements (regelendaad), conduct management (bestuurrdaad), carry out management (beheerdaad), and conduct supervision (toezichthoudendaad). In public land banks that are oriented towards development for the public interest, they must also consider the formulation and criteria of public interest in the existing regulations. Development in the public interest aims to improve public welfare and does not aim for profit or profit.

Apart from that what is called the public interest, concerns the interests of the nation and state, public services in the wider community, the people, and development. Speaking of public interests, it should be noted that not every government interest always aims for the public interest, such as port development, indeed it is the government's interest, but not the public interest, because in the end it will be managed by SOEs that are always oriented to seeking profit in order provide income to the state and the SOE itself. On the other hand, this does not provide benefits to the wider community and people.

So, the forms of public interest activities still have to be explained about the extent to which the functions of public interest will result from certain forms of public interest activities so that they are called public interests. Based on Law No. 20 of 1961 concerning the revocation of land rights, broadly defined public interests, among others, for interests of the nation, the common interest of the people, and the interests of development. In the clarification of Law No. 20 In 1961 it was $m$ clear that public interest activities were not confined to governmental activities, but they could also be undertaken by the private sector as long as they were in the public interest. In-Law No. 2 The year 2012 on land acquisition for development in the public interest is mentioned, public interest is the national, state, and community interests that should be established by the government and used most for the prosperity of the people.

(Article 1 (6)) From this provision it can be concluded that the activity is truly in the public interest which must con $n 3$ elements, namely: 1) The development activities are truly owned by the government. In this case, public interest activities cannot be owned by individuals or private parties. In other words, private and individuals cannot have the types of public interest activities that require land acquisition, both land rights, and state land; 2) The development activities are carried out by the government. This element shows that the process of implementing and managing activity in the public interest can only be played by the government; 3) The development activities are not for profit (non-profit). In this element the limits of the function of activity in the public interest are completely different from the private interest which aims to seek profits, so the qualification of an activity is for a public purpose activity if absolutely not seeking profit.

From the description above, the presence of a public land bank institution can be a solution in the context of difficulties in the acquisition of land for the public interest, because the public land bank institution functions as a land reserve institution that guarantees while ensuring that development activities for the public interest is carried out effectively, efficiently, and sustainable. This is in accordance with one of the objectives of land banks as a means of land management that guarantees the availability of land for certain purposes. Some public interests that can be anticipated by public land banks including public land banks include: 1) Land for the relocation of communities affected by natural disasters, fires, and conflicts; 2) Land for urban development and low-income population settlements; 3) Land to substitute land for the 
owner/holder of land rights in the land acquisition/land acquisition project; 4) Landbank for city safety belt, which is the area around the city that serves to restrain the rate of expansion of the city, especially the conversion of agricultural land for uncontrolled housing and industry, which is also a water catchment area and a green open area to prevent natural disasters.

The similarities between land banks and conventional banks (Ganindha, 2017; Zahra, 2017; Mochtar, 2013), namely 1) In terms of the functions, they can store assets together, help stabilize the secondary market, hold capital reserves; 2) In terms of implementation both can be run by both the government and the private sector; 3) In terms of operationalization both operate within a regulatory framework. While the differences are: 1) The land bank has the duty to save and manage the land, while the conventional bank has the duty to save and manage money and valuable objects and other securities; 2) Land banks focus on environmental and community stabilization and land use planning, while conventional banks focus on national and international markets; 3) Priority-based land banks are not-for-profit even though there are also profit-oriented ones especially those managed by the private sector, whereas conventional banks are more profit-oriented.

\section{Land Bank Business Model}

Land banks have long been applied in various countries with a variety of special missions that are adapted to the condition s that are happening at the moment and look at future goals to be achieved. In the United States, a land bank was built to deal with the phenomenon of abandoned vacant property and accelerate the rebuilding of the environment, and strive to provide affordable housing for the community. This is done to secure the property from land speculators with strong capital. Over time, land banks in the United States also accommodate the provision and provision of land for industrial activities. This is similar to land banks in Colombia. Metro Vivienda which is located in Bogota as a land bank has a mission to provide land for housing development (Echeverria, 1991). The Colombian land bank applies land purchases in the suburbs to be made affordable housing (Echeverria, 1991). In land distribution, Colombian land banks divide it up for commercial, housing, and institutional interests.

The Netherlands (Spit, 2018) and the Philippines (Overholt, 1976) organized land banks to support activities in the agricultural sector. In its development, the Land Bank of the Philippines grew into a commercial bank while continuing to carry out the country's social mandate. The same thing is run by the Land Bank of Taiwan (Li, 2021).

The land acquisition process is a challenge for land banks. Described several mechanisms of land banks in several countries. The Japanese state determines a policy that a person who buys land and then resells the land in less than 10 years from the time the land is purchased, is categorized as land speculation activities and therefore subject to very high taxes. Guatemala applies a way to provide tax relief to each landowner who sells his land to the state, whereas if it does not sell to the state it will be subject to high taxes. The Swiss government managed to collect nearly $40 \%$ of the land in the country by implementing a rule that every citizen who would sell his land must report to the local government. Whereas the Dutch implemented the regulation that the landowners who did not use it within a certain period of time, the land was taken by the state by providing compensation. With the provisions and regulations in some of these countries, it is evident that Switzerland and the Netherlands are small states whose land has succeeded in building land banks for development for the people. 


\section{How to Implement Land Banks In Indonesia?}

Considering the current condition of Indonesia, the government first needs to focus on the policy of providing land for infrastructure and public housing. In line with the government program regarding infrastructure development and the provision of affordable housing for the middle to lower economic community. Therefore, it is important to build a One Map Policy meth ad in land management that is adjusted to the government's Ion g-term plan so that landuse zoning can be determined for equitable development.

Procurement activities need to be divided into three categories. First, inventory and full control of the land controlled by the state include former HGU land, abandoned land, social land/falsum land surrendered by the developer, land assets of I BRA, land assets of BUM N / BUMD that have not been used, idle assets at the Ministry/ Institution / Local Government, state land from revocation of rights and state land originating from land acquisition. Second, urgent land purchases must be carried out immediately / immediately to be used in the implementation of the planned development. In this land acquisition, Indonesia can adopt a scheme implemented in Guatemala, where parties/individuals who are unwilling to sell their land to the state for public purposes will be subject to very high taxes. Third, land acquisition to be reserved (investment). As a land bank, of course, it is necessary to have sufficient land reserves and must be aligned with the government 's long-term development plans.

To carry out procurement with the purpose of backing up, Indonesia can implement methods that are also applied in the Netherlands and Japan. To encourage increased tax revenues, Indonesia can impose a policy that every party that buys land and resells it within a certain period of time (less than 10 years) will be subject to very high taxes. And in order to encourage the optimization of land use by all parties, regulations can be applied that land that is not used within a certain period of time will be taken by the state with compensation, if the party/person does not agree, then the first rule regarding the imposition of very high taxes on land. With this mechanism, it is hoped that land located throughout Indonesia can be optimized for productive land or utilized for the benefit of the people, thereby suppressing land speculators.

In addition to procurement activities, land banks must be aggressive in the security and maintenance functions of land that have been controlled by applying standardization in security. Based on several cases that occur, a lot of state land is occupied by unlicensed citizens and this lasts for years. This indicates the existence of security and maintenance processes that need to be improved. In addition, to maintain the availability of land for common interests and development, the government should actively participate in controlling the property development movement by the private sector. It must be stricter and more harmonized with the One Map Policy.

The development of technology requires Indonesia to apply the latest technology in the management of this land. Indonesia can emulate the Philadelphia Land Bank, USA, which has managed and developed land according to long-term strategic objectives by utilizing the Geographic formation System (GIS) which is integrated with the decision-making system that they developed. GIS is a computer system that has the ability to build, store, manage and display geo-referenced information, for example, data identified by location, in a database (wikipedia.org). This system can certainly be applied in the implementation of the One Map Policy.

Key components of Successful Land Bank Implementation

There are several factors that determine the success or failure of land banks, including: 1) Regulation. As explained above, the recommended regulations for land banks are in the form of laws, so that they have binding legal force. The regulation will force the land bank to work 
according to its functions and objectives so that it will bring justice and encourage increased prosperity of the people. In addition to the large number of stakeholders involved in land banks, regulations will guarantee the equal interests of all stakeholders (government, private, community).

Land bank regulation should contribute to the following aspects: a) To improve the welfare of the people to achieve prosperity; b) Increase the welfare of the community with justice through the distribution of land; c) Providing physical land for sustainable development in the public interest or commercial interests; d) Can control the price of land so that it is affordable for all levels of society. 2) Institutional land bank. For Indonesia, land bank operators should be in the form of public legal entities, this is because land banks have great authority and responsibility regarding the interests of the public so the government must play an active role in the implementation of land banks.

This land bank can carry out the tasks of the BPN, among others: a) To coordinate policies, planning in the field of land by compiling a plan for the supply, designation, use, and maintenance of land through land stewards in the level II region) Carry out monitoring and control of land ownership by carrying out monitoring and evaluation on the use and utilization of land also in the context of land redistribution, including on land consultation; c) Carry out land management in the field of land information. 3) Land bank financing. The issue of land bank financing is very important especially at the implementation stage. Land bank financing depends on many factors such as the structure of the land bank, the purpose of the land bank, scale of operations, etc. Thus, the land bank is very highly dependent on the existence of a stable and sustainable source of funds.

In the world of land bank funding, there are generally two forms of funding assistance: a) assistance. This assistance is usually given by a country or international funding agency to a particular country and is related to certain development programs; b) Project assistance. This assistance is provided in the form of financing facilities to finance various development projects, which can be in the form of grants, loans, or investments. This funding is generally provided by government agencies, donor agencies, non-profit / non-government organizations, and financial institution [4]

Other factors that are also determinants of the success of land banks such as: a) Political will from the main government in making regulations; b) RTRW, this regional spatial plan is a guideline in planning activities related to the allocation of land so that it can be utilized as much as possible without damaging the environment; c) Human resources, no less important for the success of land banks, the human resources who play a role in land banks must have quality and professional expertise so that the implementation of land banks is efficient.

\section{Conclusion}

Land acquisition in the implementation of development which always faces problems that cause physical development in all fields faltered or even floated due to inadequate regulation and the occurrence of a shift in political economy from a populist economy to a capitalist economy, neoliberalism makes commodity land that triggers land liberalism and land prices to soar high caused by soil speculators. One of the breakthroughs to overcome the complexity of the problem of land acquisition for development purposes is the application of land banks that function as land collectors, as land safeguards to secure the provision and designation and use of land in accordance with the spatial plan that has been approved. 
In addition, the land bank functions as a land controller, as an appraiser of land that can suppress the emergence of land speculators, and as the distribution of land in accordance with development programs and spatial plans that also function to direct land use in urban development and a certain area. The concept of a land bank is very potential to be applied in Indonesia in the form of a public land bank, bearing in mind the provisions of artic 3 paragraph 3 of the 1945 Constitution of the Republic of Indonesia and article 2 of the LoGA, that the state has an important role in implementing a land bank.

The application of a Land Bank in Indonesia is an urgent necessity. The government must coordinate with all relevant parties, starting from the Ministries / Institutions to the interested private institution s to be able to develop an appropriate One Map Policy. With this One Map Policy, it is expected that asset management is more planned and can be optimized for the public interest. The above opinion is the personal opinion of the author, so it needs a more in-depth study that is adjusted to the government's long-term strategic plan in the application of the Land Bank in Indonesia. With the formation of the LMAN Public Service Agency (State Asset Management Institute) by the government, LMAN is expected to be able to become an optimal institution in carrying out the function of asset optimization with the application of this land bank.

\section{References}

[1] Amir, Z. A., Hendropriyono, A. M., Ladiqi, S., Kawuryan, M., \& Arif, A. (2020). "Implementation of Acceleration of Indonesian Infrastructure Development In Improving National Economic Growth Under The Government of Joko Widodo Period 2014-2019." PalArch's Journal of Archaeology of Egypt/Egyptology, 17(4), 1483-1494.

[2] Brown, A. L., Fleming, K. L., \& Safford, H. R. (2020). Prospects for a Highly Electric Road Transportation Sector in the USA. Current Sustainable/Renewable Energy Reports, 1-10. https://doi.org/10.1007/s40518-020-00155-3

[3] Cantarero, M. M. V. (2020). Of renewable energy, energy democracy, and sustainable development: A roadmap to accelerate the energy transition in developing countries. Energy Research \& Social Science, 70, 101716. https://doi.org/10.1016/j.erss.2020.101716

[4] Echeverria, M. C. (1991). Urban reform in Colombia: A tool for democratic development?. Cities, 8(2), 108-119. https://doi.org/10.1016/0264-2751(91)90004-B

[5] Eisenmenger, N., Melanie P., Nora K., Dominik N., Barbara P., Ekaterina S., Marie-Theres W., and Simone G. (2020). "The Sustainable Development Goals prioritize economic growth over sustainable resource use: a critical reflection on the SDGs from a socio-ecological perspective." Sustainability Science 15: 1101-1110. https://doi.org/10.1007/s11625-020-00813-x

[6] Febrianto, S. (2020, December). The State of Indonesia Needs Investment to Accelerate Infrastructure Development After New Normal Policies Due to Covid-19. In The 2nd International Conference of Law, Government and Social Justice (ICOLGAS 2020) (pp. 447-465). Atlantis Press.

[7] Ganindha, R. (2017). "Urgensi Pembentukan Kelembagaan Bank Tanah sebagai Solusi Pengadaan Tanah Bagi Pembangunan untuk Kepentingan Umum yang Nirkonflik [The Urgency of Establishing a Land Bank Institution as a Solution for Land Acquisition for Development for Non-Conflict Public Interest]." Arena Hukum, 9(3), 442-462.

[8] Gunawan, J., Permatasari, P., \& Tilt, C. (2020). Sustainable development goal disclosures: Do they support responsible consumption and production?. Journal of Cleaner Production, 246, 118989. https://doi.org/10.1016/j.jclepro.2019.118989

[9] Harry, M., Wahidi, A., \& Musataklima, M. (2020). Land bank and food sovereignty in Indonesia.

[10] Lélé, S. M. (1991). "Sustainable development: a critical review." World development, 19(6), $607-$ 621. 
[11] Li, T. M. (2021). Commons, co-ops, and corporations: assembling Indonesia's twenty-first century land reform. The Journal of Peasant Studies, 48(3), 613-639. https://doi.org/10.1080/03066150.2021.1890718

[12] Limbong, B. (2015). Pengadaan Tanah Untuk Pembangunan [Land Acquisition for Development]. Jakarta: Margaretha Pustaka.

[13] Mochtar, H. (2013). "Keberadaan Bank Tanah Dalam Pengadaan Tanah Untuk Pembangunan[The existence of a land bank in land acquisition for development]." Jurnal Cakrawala Hukum, 18(2).

[14] Munasinghe, M. (1999). "Is environmental degradation an inevitable consequence of economic growth: tunneling through the environmental Kuznets curve.” Ecological economics, 29(1), 89-109. https://doi.org/10.1016/S0921-8009(98)00062-7

[15] Overholt, W. H. (1976). Land reform in the Philippines. Asian Survey, 16(5), 427-451.

[16] Republic of Indonesia. Peraturan Presiden Nomor 71 Tahun 2012 tentang Penyelenggaraan Pengadaan Tanah bagi Pembangunan untuk Kepentingan Umum [Presidential Regulation Number 71 of 2012 concerning the Provision of Land Procurement for Development in the Public Interest]. LN.2012/No.156.

[17] Republic of Indonesia. Undang-Undang Nomor 2 Tahun 2012 tentang Pengadaan Tanah Bagi Pembangunan Untuk Kepentingan Umum [Law Number 2 of 2012 concerning Land Procurement for Development in the Public Interest]. LN.2012/No. 22, TLN No. 5280.

[18] Republic of Indonesia. Undang-Undang Nomor 20 Tahun 1961 tentang Pencabutan Hak-Hak Tanah dan Benda-Benda Yang Ada Diatasnya [Law No. 20 of 1961 concerning the revocation of land rights]. LN. 1961 No. 288, TLN No. 2324.

[19] Rohman, H., \& Wahono, D. C. (2020). "Indonesia's International Trade Policy in the 2015-2019 National Medium-Term Development Plan in Realizing Food Security and Sovereignty.” Indonesia's Path Toward Middlepowership, 139.

[20] Spit, T. (2018). Strategic land banking in the Netherlands: Experiencing Dutch dilemmas. In Instruments of Land Policy (pp. 271-283). Routledge.

[21] State Speech of the President of the Republic of Indonesia and Government Statement. "Concerning the Draft Law on the State Revenue and Expenditure Budget for the 2007 Fiscal Year and its Financial Notes." The House of Representatives Session, 16 August 2006. Available at: https://www.bappenas.go.id/id/data-dan-informasi-utama/dokumen-perencanaan-danpelaksanaan/pidato-kenegaraan-tahun-2006/

[22] Sumardjono, M. S. (2005). Kebijakan pertanahan: antara regulasi dan implementasi [Land policy: between regulation and implementation]. Jakarta: Kompas.

[23] Syed Mustorpha S.N.A., Tuan Besar T.B.H. (2020). "A Compilation and Analysis of Key Criteria for Land Bank Development. In: Kaur N., Ahmad M. (eds) Charting a Sustainable Future of ASEAN in Business and Social Sciences." Springer, Singapore. https://doi.org/10.1007/978-981-15-3859$9+40$ 